\title{
Levels of polychlorinated biphenyls and organochlorine pesticides in serum samples of Egyptian Vulture (Neophron percnopterus) from Spain
}

\author{
B. Gómara a , L. Ramos ${ }^{\text {a }}$, L. Gangoso b , J.A. Donázar ${ }^{\text {b }}$, M.J. González ${ }^{\text {a,* }}$ \\ a Department of Instrumental Analysis and Environmental Chemistry, IQOG (CSIC), Juan de la Cierva, \\ 3, 28006 Madrid, Spain \\ ${ }^{\mathrm{b}}$ Department of Applied Biology, EBD (CSIC), Pabellón del Perú, Avenida de Maria Luisa, s/n. 41013 Sevilla, Spain
}

\begin{abstract}
Concentrations of 23 polychlorinated biphenyls (PCBs), p, $\mathrm{p}^{0}$-DDT and two of its metabolites, $\mathrm{p}, \mathrm{p}^{0}-\mathrm{DDE}$ and $\mathrm{p}, \mathrm{p}^{0}-$ TDE have been measured iß serum samples of up to $1 \mathrm{ml}$ of Egyptian Vulture (Neophron percnopterus) gathered from five populations in Spain. PCB concentrations were found to be in the range 3.2-97 ng/ml, while those of DDTs ranged from 0.93 to $38 \mathrm{ng} / \mathrm{ml}$. p, $\mathrm{p}^{0}$-DDT/p, $\mathrm{p}^{0}$-DDE ratios higher than one were only found in the Segovia population, which could be an indication of recent use of $\mathrm{p}, \mathrm{P}^{0}-\mathrm{DDT}$ in the area. In all cases, PCB profiles were dominated by congeners 52, 132+105, 138, 153 and 180. However, some differences among the five populations studied became evident when their profiles were compared with those of technical PCB mixtures by principal components analysis. The DDT and PCB levels detected in the serums analysed were lower than those previously reported for similar avian species and those reported to have deleterious effects on survival or reproduction of birds.
\end{abstract}

Keywords: PCBs; DDTs; Serum analysis; Egyptian Vulture; Principal components analysis

\section{Introduction}

Polychlorinated biphenyls (PCBs) are well-known environmental contaminants found world-wide and able to concentrate in living organisms, in particular at upper levels in both terrestrial and marine trophic chains (Tanabe and Tatsukawa, 1991; Moessner and Ballschmiter, 1997). Among the 209 possible PCB congeners, attention was initially focused in those characterised by their relative high abundance in the environment. However, in recent years, attention has also been extended to a few less abundant PCBs showing toxicity

\footnotetext{
* Corresponding author. Tel.: +34-91-5622900; fax: +34-915644853.

E-mail address: mariche@iqog.csic.es (M.J. González).
}

similar to that of polychlorinated dibenzo-p-dioxins (PCDDs) and polychlorinated dibenzofurans (PCDFs) (Ballschmiter and Zell, 1980; van den Berg et al., 1998) and for which the World Health Organisation (WHO) has established toxic equivalency factors (TEFs) for risk assessment (van den Berg et al., 1998) in humans/ mammals, fish and birds. In the latter, the presence of PCBs has been found responsible for embryonic deformities and reduction in reproductive success in a variety of species (Hoffman et al., 1998; Fernie et al., 2000).

2,2-Bis(4-chlorophenyl)-1,1,1-trichloroethane ( $\mathrm{p}, \mathrm{p}^{0}$ DDT) and its two main metabolites, 2,2-bis(4-chlorophenyl)-1,1-dichloroethylene (p, $\mathrm{p}^{0}$-DDE) and 2,2bis-(4-chlorophenyl)-1,1-dichloroethane ( $\left.\mathrm{p}, \mathrm{p}^{0}-\mathrm{TDE}\right)$ are persistent and toxic organochlorine pesticides showing endocrine disruption activity and causing eggshell thinning and embryo deaths in several species of birds. 
Among them, raptor species such as Egyptian Vulture (Neophron percnopterus) have been reported to be particularly sensitive to this group of pollutants (WHO, 1989).

Despite its wide use in the past, environmental concentration of $\mathrm{p}, \mathrm{p}^{0}$-DDT in Spain have declined since this chemical was banned in 1977. Nevertheless, levels of DDTs at higher concentrations than those associated with their past use have recently been detected in various ecosystems in Spain (Fernández et al., 2000; Gómara et al., 2002a). These findings could be associated with occasional use of $\mathrm{p}, \mathrm{p}^{0}$-DDT after banning.

Egyptian Vulture is a small predatory vulture species in danger of extinction, which inhabits open landscapes in arid and rugged regions where it exploits carcasses of small and medium-size animals. Egyptian Vulture populations have decreased sharply during the last century being considered the Iberian Peninsula populations among the most important in the world (Donázar et al., 2002).

In this paper, an analytical method previously validated (Gómara et al., 2002b) for the determination of PCB levels in serum samples of up to $1 \mathrm{ml}$ has been used to measure the concentration of 23 PCBs (including the most toxic and abundant congeners) as well as $\mathrm{p}, \mathrm{p}^{0}$ DDT, p, $\mathrm{p}^{0}$-DDE and $\mathrm{p}, \mathrm{p}^{0}-\mathrm{TDE}$ in serum of 27 individuals of Egyptian Vulture gathered from five populations placed in different regions in Spain. The PCB profiles found in the Egyptian Vulture serum samples investigated were compared to those of technical PCB mixtures by using principal components analysis (PCA) in an attempts to identify possible differences in the sources of the PCB levels detected.

\section{Materials and methods}

\subsection{Chemicals}

All solvents were pestipur quality and were purchased from SDS (Peypin, France), except hexane (Merck, Darmstadt, Gremany) and acetonitrile (Fisher, Pittsburgh, PA, USA). Formic and sulphuric acids (analysis quality) and silica gel 60 were from Merck, anhydrous sodium sulphate from J.T. Baker (Deverter, The Netherlands) and cartridges of Oasis HLB $(60 \mathrm{mg})$ used for solid phase extraction (SPE) from Waters (Milford, USA). Individual standards of the selected analytes were purchased from Ehrenstorfer (Augsburg, Germany). Aroclors 1242, 1254 and 1260 were used for statistical comparison of the PCB profiles found in environmental samples.

\subsection{Samples}

The 27 serum samples analysed were gathered from live Egyptian Vulture (N. percnopterus) individuals from

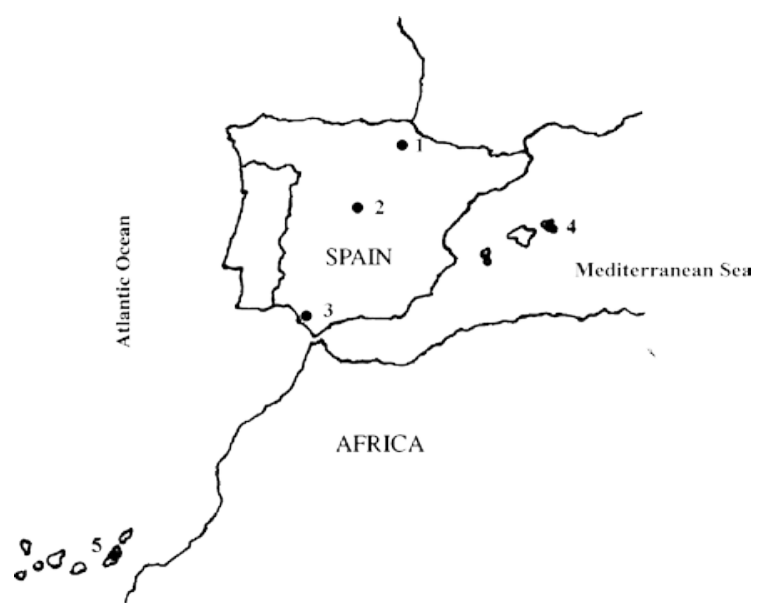

Fig. 1. Geographical location of the population studied: (1) Navarra, (2) Segovia, (3) Cádiz, (4) Menorca Island, and (5) Fuerteventura Island.

five populations in Spain between 1999 and 2001 (see Fig. 1 for location). Navarra (station 1, six samples), corresponding to an industrial area, and Segovia (station 2, three samples) and Cádiz (station 3, three samples), located in rural areas, were sampled during the springsummer season as Egyptian Vultures inhabiting these areas migrate to Africa for wintering (Donázar et al., 2002). Sedentary populations in Menorca Island (station 4, two samples) and Fuerteventura Island (station 5, 13 samples) inhabit zones close to residential and rural areas and were sampled in May and September, respectively. In each station, samples were taken the same day and from controlled individuals to prevent duplicated sampling of the same animal (Donázar et al., 2002).

\subsection{Experimental}

Blood samples were taken from live Egyptian Vulture individuals, collected in glass tubes, kept at $4{ }^{\circ} \mathrm{C}$ for 30 min and centrifuged (Microfuge 11, Beckman, CA, USA) at $3000 \mathrm{rpm}$ for $10 \mathrm{~min}$ to yield serum samples of 0.18-1.3 ml. Individual samples were conserved at ) 20 ${ }^{\circ} \mathrm{C}$ until processed according to a previously validated SPE-based method described elsewhere (Gómara et al., $2002 b$ ) which has also been tested by participation in the AMAP interlaboratory exercise (Ring test for PCBs and OCs, National Institute of Public Health, Quebec, Canada). Briefly, the analytical procedure consisted on SPE of the target compounds using an Oasis cartridge (Waters, HLB $60 \mathrm{mg} / 3 \mathrm{ml}$ ) previously conditioned with 2 $\mathrm{ml}$ of dichloromethane, $2 \mathrm{ml}$ of methanol and $2 \mathrm{ml}$ of Milli-Q water. And subsequent on-line fat removal by elution of the extraction solvent ( $3 \mathrm{ml}$ of toluene) through a multilayer column containing $60 \mathrm{mg}$ of silica 
gel activated at $140{ }^{\circ} \mathrm{C}$ for $48 \mathrm{~h}, 240 \mathrm{mg}$ of silica modified with sulphuric acid $(44 \%$, w/w) and anhydrous sodium sulphate. Quantification was carried out by gas chromatography (GC) with micro-electron capture detection (micro-ECD) using PCB 209 and 1,2,3,4-tetrachloronaphtalene (TCN) as internal standards.

Blank samples were analysed to identify any contamination throughout the analytical procedure. No background interference was found to be introduced by the methodology proposed. The limits of detection (LODs) calculated for real-life serum samples were in the range $0.01-0.30 \mathrm{ng} / \mathrm{ml}$ of serum and the relative standard deviations of the complete method were better than $18 \%$, irrespective of PCB concentration levels (Gómara et al., 2002b).

Determination of $\mathrm{p}, \mathrm{p}^{0}-\mathrm{DDT}, \mathrm{p}, \mathrm{p}^{0}-\mathrm{DDE}, \mathrm{p}, \mathrm{p}^{0}-\mathrm{TDE}$ and PCB congener levels in the final extracts was performed by GC-micro-ECD (HP 6890 Series, HewlettPackard, Palo Alto, CA). Samples were injected in the hot splitless mode $\left(1 \mathrm{1l}, 270{ }^{\circ} \mathrm{C}\right.$, splitless time $\left.1.0 \mathrm{~min}\right)$ on a capillary DB-5 column (5\% phenyl $95 \%$ methyl silicone, $60 \mathrm{~m}, 0.25 \mathrm{~mm}$ i.d., $0.25 \mathrm{Im}$ film thickness) purchased from J\&W Scientific (USA). The column temperature was programmed from $80{ }^{\circ} \mathrm{C}(2 \mathrm{~min})$ to $185^{\circ} \mathrm{C}(3 \mathrm{~min})$ at a rate of $30^{\circ} \mathrm{C} / \mathrm{min}$, then to $230^{\circ} \mathrm{C}(15$ $\mathrm{min})$ at $1.5^{\circ} \mathrm{C} / \mathrm{min}$, and then to $270{ }^{\circ} \mathrm{C}(15 \mathrm{~min})$ at $5{ }^{\circ} \mathrm{C} /$ min. Nitrogen was used as carrier gas (constant flow, 1.5 $\mathrm{ml} / \mathrm{min})$ and as make-up gas $(30 \mathrm{ml} / \mathrm{min})$. The detector temperature was set at $300^{\circ} \mathrm{C}$.

\subsection{Multivariate analysis}

A database containing the normalised PCB concentration of the congeners studied in the 27 serums samples and those found in three PCB technical mixtures (Aroclor 1242, 1254 and 1260) was prepared. Normalisation of data was carried out by expressing the concentration of individual congeners (variables) as a percentage of the sum of PCBs to minimise any statistical bias associated with order of magnitude differences in the concentrations of the analytes. The statistical analysis was carried out using the Statgraphics 5.0 program (STSC, Inc., USA).

\section{Results and discussion}

\subsection{DDT and PCB levels in serum samples}

Table 1 summarises the geometric means and range of concentrations calculated of DDTs and PCBs (as $\mathrm{ng} / \mathrm{ml}$ of serum) found in the serum of individuals collected from the five Egyptian Vulture populations.

The highest levels of the sum of DDTs (i.e. concentrations of $\mathrm{p}, \mathrm{p}^{0}-\mathrm{DDE}$ plus $\mathrm{p}, \mathrm{p}^{0}-\mathrm{TDE}$ plus $\mathrm{p}, \mathrm{p}^{0}-\mathrm{DDT}$,
$\mathbf{P}$

DDT) were detected in individuals from station 5 , Fuerteventura Island (mean $1 / 46.2 \mathrm{ng} / \mathrm{ml} ;$ max $1 / 438 \mathrm{ng} /$ $\mathrm{ml})$. The DDT geometric mean calculated for serums from this population was rather similar to that found in the other sedentary population studied, station 4 in

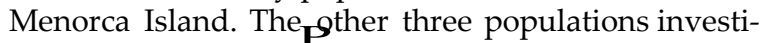
gated showed lower DDT than those found in the island populations; the range of geometric means was $4.9 \mathrm{ng} / \mathrm{ml}$ for individuals trapped at station 3 (Cadiz), and $2.0 \mathrm{ng} / \mathrm{ml}$ for those captured in station 2 (Segovia).

The differences in the DDT levels detected in the five Egyptian Vulture populations could probably be related to the characteristics of their habitats and migratory habits. Vultures with the highest values of DDT (Menorca and Fuerteventura populations) are sedentary, while the other three populations, which exhibited lower DDT levels, winter in the African Sahel region after nesting on the Iberian Peninsula.

As it is well known, $\mathrm{p}, \mathrm{P}^{0}$-DDE is greatly associated with eggshell thinning in many bird species (Dirksen et al., 1995; Konstantinou et al., 2000). Among the three DDTs, $\mathrm{p}, \mathrm{p}^{0}$-DDE was found to be the most abundant in the bird serums analysed, with concentrations ranging from 0.47 to $38 \mathrm{ng} / \mathrm{ml}$ (Table 1). However, these levels are far below the concentration in eggs that has been correlated with toxic effects in different bird species $(=5$ $1 \mathrm{~g} / \mathrm{g}$ fresh weight) (Hoffman et al., 1998). According to the results obtained by Iseki et al. (2001) the concentration of POPs in eggs are similar to those found in blood samples.

Except for station 2, the DDT profile found in the serum samples from all Egyptian Vulture populations studied was that expected from areas where $\mathrm{p}, \mathrm{P}^{0}$-DDT has not been recently used (Solé et al., 1994; van Wyk et al., 2001), i.e. p, $\mathrm{p}^{0}$-DDE levels were higher than those of $\mathrm{p}, \mathrm{p}^{0}$-DDT and both higher than those of $\mathrm{p}, \mathrm{p}^{0}-\mathrm{TDE}$. The calculated $\mathrm{p}, \mathrm{p}^{0}-\mathrm{DDT} / \mathrm{p}, \mathrm{p}^{0}-\mathrm{DDE}$ mean ratio was lower than one at all stations, except in samples from station 2. At this sampling point, a mean ratio of 1.2 was calculated, a value that could be associated with recent exposure to p, $\mathrm{p}^{0}$-DDT in the area (Sericano et al., 1990; Solé et al., 1994). Despite the large amount of data reported related to DDT levels in eggs of raptor species, studies on the determination of DDT levels in blood or serum samples of avian species are scarce in the literature (van Wyk et al., 1993a,b, 2001). DDT concentrations found in the serum analysed in the present study are in the range of those previously detected in blood samples of vultures from different locations in South Africa in 2001 (range $1 / 41.4-56$ ng/ml) (van Wyk et al., 2001), although they are lower than those found in vultures from the same country before 1993 (average concentration $1 / 489 \mathrm{ng} / \mathrm{ml}$ ) (van Wyk et al., 1993a,b).

As can hs seen from the sum of the 23 PCB congeners analysed ( PCBs, Table 1), some differences existed among the five populations investigated. Egyptian Vulture 
Table 1

Geometric mean and range of concentrations of PCBs and DDTs in serum of Egyptian Vulture from five Spanish populations (ng/ml)

\begin{tabular}{|c|c|c|c|c|c|}
\hline Compound & $\begin{array}{l}\text { Station } 1 \text { (n } 1 / 46) \\
\text { (Navarra) }\end{array}$ & $\begin{array}{l}\text { Station } 2 \text { (n } 1 / 43 \text { ) } \\
\text { (Segovia) }\end{array}$ & $\begin{array}{l}\text { Station } 3 \text { (n 1/4 3) } \\
\text { (Cádiz) }\end{array}$ & $\begin{array}{l}\text { Station } 4 \text { (n } 1 / 42 \text { ) } \\
\text { (Menorca) }\end{array}$ & $\begin{array}{l}\text { Station } 5 \text { (n } 1 / 413 \text { ) } \\
\text { (Fuerteventura) }\end{array}$ \\
\hline PCB 28 & 0.61 (ND-5.4) & 0.06 (ND-0.06) & ND & ND & $0.61(0.24-1.5)$ \\
\hline РCB 52 & $3.3(1.0-6.3)$ & $2.7(2.2-4.1)$ & $1.2(\mathrm{ND}-3.8)$ & $0.46(0.44-0.49)$ & $0.60(0.18-2.4)$ \\
\hline PCB 95 & $1.0(0.45-3.1)$ & $0.30(0.19-0.47)$ & 0.25 (ND-0.50) & $0.23(0.19-0.27)$ & $0.91(0.28-3.0)$ \\
\hline РСВ 101 & $1.3(0.55-5.1)$ & $0.29(0.23-0.35)$ & 0.32 (ND-0.60) & $0.34(0.33-0.35)$ & $1.3(0.52-7.3)$ \\
\hline PCB 77+110 & $1.4(0.73-4.1)$ & 0.08 (ND-0.15) & ND & 0.14 (ND-0.14) & $0.58(0.03-3.0)$ \\
\hline PCB $123+149$ & $0.43(0.13-2.1)$ & $0.04(0.03-0.09)$ & 0.20 (ND-0.20) & 0.03 (ND-0.03) & 0.26 (ND-0.86) \\
\hline PCB 118 & $0.42(0.15-2.4)$ & $0.08(0.04-0.17)$ & 0.18 (ND-0.62) & $0.38(0.22-0.65)$ & $0.37(0.04-2.4)$ \\
\hline РCB 114 & $0.14(0.05-0.6)$ & ND & ND & ND & ND \\
\hline PCB 153 & $1.8(0.50-20)$ & $0.54(0.32-1.2)$ & $1.6(0.59-5.6)$ & $4.1(1.7-10)$ & $2.7(0.66-17)$ \\
\hline PCB $132+105$ & $6.0(2.0-36)$ & $0.28(0.20-0.40)$ & $0.36(0.09-1.0)$ & $0.92(0.73-1.2)$ & $7.3(1.8-27)$ \\
\hline PCB 138 & $1.1(0.27-11)$ & $0.26(0.15-0.66)$ & $0.73(0.30-2.7)$ & $2.4(0.95-5.8)$ & $1.7(0.40-11)$ \\
\hline PCB $126+129+178$ & $0.25(0.14-0.70)$ & 0.12 (ND-0.65) & 0.06 (ND-0.06) & $0.05(0.02-0.18)$ & 0.17 (ND-0.43) \\
\hline PCB 183 & $0.11(0.02-2.6)$ & ND & 0.20 (ND-0.63) & $0.20(0.04-1.1)$ & 0.11 (ND-1.6) \\
\hline РCB 167 & $0.16(0.02-0.70)$ & ND & 0.15 (ND-0.15) & $0.19(0.05-0.67)$ & 0.11 (ND-0.87) \\
\hline PCB 156 & $0.22(0.06-1.8)$ & 0.06 (ND-0.06) & 0.20 (ND-0.20) & $0.12(0.03-0.45)$ & $0.11(0.02-0.44)$ \\
\hline PCB 157 & $0.30(0.10-1.4)$ & 0.09 (ND-0.13) & 0.28 (ND-0.28) & $0.09(0.02-0.39)$ & 0.11 (ND-1.1) \\
\hline PCB 180 & $1.8(0.21-18)$ & $0.40(0.28-0.78)$ & $1.8(0.77-6.6)$ & $2.8(1.1-6.7)$ & $2.0(0.47-11)$ \\
\hline РСВ 169 & 0.42 (ND-1.3) & ND & ND & 0.08 (ND-0.08) & ND \\
\hline PCB 170 & $0.30(0.05-3.7)$ & $0.10(0.07-0.12)$ & $0.43(0.15-1.7)$ & $0.94(0.35-2.6)$ & 0.44 (ND-8.1) \\
\hline PCB 189 & $0.46(0.10-2.6)$ & 0.31 (ND-0.53) & 0.01 (ND-0.01) & 0.05 (ND-0.05) & 0.52 (ND-1.4) \\
\hline PCB 194 & $0.34(0.04-3.5)$ & $0.12(0.09-0.19)$ & $0.49(0.20-1.9)$ & $0.70(0.24-2.0)$ & $0.37(0.03-1.7)$ \\
\hline DDE & $2.1(0.47-12)$ & $0.82(0.52-1.0)$ & $3.8(1.4-8.5)$ & $3.9(2.5-6.0)$ & $6.0(0.47-38)$ \\
\hline TDE & 0.17 (ND-0.24) & $0.16(0.15-0.18)$ & $0.15(0.10-0.18)$ & $0.17(0.17-0.18)$ & ND \\
\hline DDT & $1.9(0.76-5.0)$ & $1.0(0.82-1.3)$ & $0.95(0.92-0.97)$ & $1.2(0.99-1.3)$ & $0.22(0.14-0.46)$ \\
\hline $\mathbf{P}_{\text {DDTs }}$ & $4.12(2.2-17)$ & $2.0(1.6-2.5)$ & $4.9(2.4-9.7)$ & $5.2(4.1-7.1)$ & $6.2(0.93-38)$ \\
\hline
\end{tabular}

serum samples from station 1 (North of Spain) showed the highest values with a geometric mean of $22 \mathrm{ng} / \mathrm{ml}$ serum and a maximum value of $97 \mathrm{ng} / \mathrm{ml}$ serum, followed by serum samples collected from populations inhabiting the islands (station 5 in the Northwest African Atlantic coast, mean $1 / 420 \mathrm{ng} / \mathrm{ml}, \max 1 / 461 \mathrm{ng} / \mathrm{ml}$; and station 4 in the Mediterranean coast of Spain, mean $1 / 414 \mathrm{ng} / \mathrm{ml}$, max $1 / 433 \mathrm{ng} / \mathrm{ml})$. The lowest PCB levels were found in serum gathered from migratory populations in the South (station 3, mean $1 / 48.5 \mathrm{ng} / \mathrm{ml}$, $\max 1 / 426 \mathrm{ng} / \mathrm{ml}$ ) and in the centre (station 2, mean $1 / 45.8$ $\mathrm{ng} / \mathrm{ml}, \mathrm{max} 1 / 47.0 \mathrm{ng} / \mathrm{ml}$ ) of Spain.

Despite the differences observed in PCB concentrations found in the five populations investigated, in general, rather similar average $\mathrm{PCB}$ profiles were obtained in all cases (Fig. 2). Not unexpectedly, PCB 52, $132+105,138,153$ and 180 were found to be the most abundant congeners among those studied, and PCB 114 and 169 were the least abundant. Nevertheless, some differences existed among the relative contributions of the rest of PCBs investigated for the five populations: samples from stations 3 and 4 showed lower contributions for PCB 28, 95, 101, 77, 126 and 189 than those calculated for the rest of the sampling points, while the opposite trend was observed for PCB 118, 183, 167, 170, and 194.
Data reported concerning PCB levels in serum are very scarce in the literature. Kumar et al. (2002) reported concentrations of PCBs in serum of black and turkey vultures from South Carolina ranging from 1.6 to $15 \mathrm{lg} / \mathrm{ml}$. Meanwhile, much higher levels have been reported for black eagles from Michigan, in the range $46-67 \mathrm{ng} / \mathrm{g}$ wet weight (Kannan et al., 2002). Total PCB levels found in our study are lower than those found in black eagles and far below those detected in vultures from South Carolina. More importantly, PCB levels detected in the samples collected in Spain are much lower than those reported for eggs $(4.7 \mathrm{lg} / \mathrm{g}$, Hoffman et al., 1993) and that have been associated with toxic effects in birds. As it was mentioning previously, POPs concentrations in eggs are similar to those found in blood samples (Iseki et al., 2001).

\subsection{Multivariate analysis}

Visual observation of the geometric mean values did not allow proper classification of the individuals investigated according to their differences in the PCB profiles in order to determine whether they were subjected to similar or different sources of contamination. Therefore, chemometric techniques, such as Multivariate Analysis, were used in an attempt to reveal possible similarities 


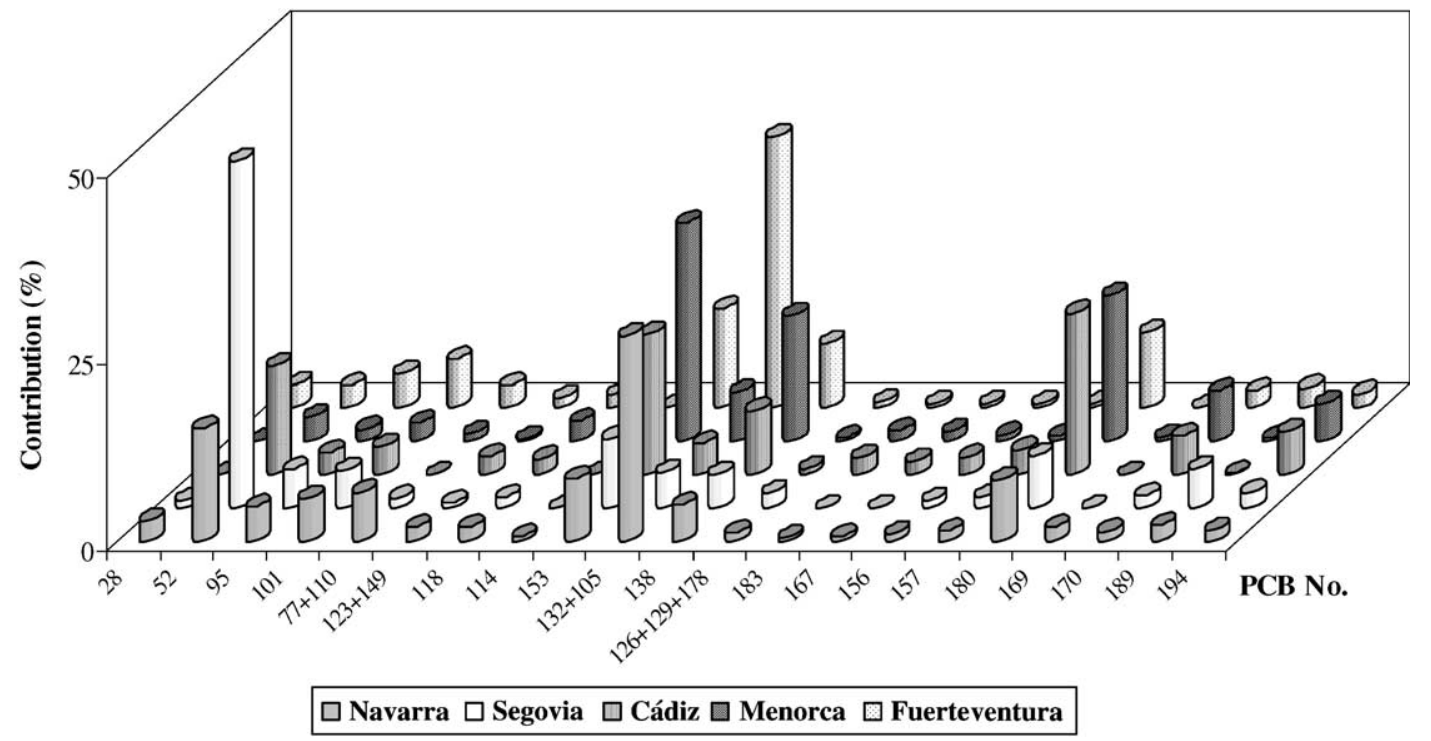

Fig. 2. Normalised PCB profiles in serum samples of Egyptian Vultures from five populations in Spain.

and differences in the PCB profiles of the serum investigated (Jiménez et al., 1998; Serrano et al., 2000).

PCA was selected to carry out the comparison. PCA is a Multivariate Analysis technique for dimension reduction (Wold et al., 1984), which allows pattern recognition in complex data sets (de Boer et al., 1993). In this study, PCA was applied to compare the PCB profiles of the 27 Egyptian Vulture serums collected in the five populations sampled with PCB profiles calculated for the technical mixtures most frequently used in industry, i.e. Aroclor 1224, 1254 and 1260. The analysed data set corresponded to the normalised contribution of the 23 PCB congeners and the Aroclor mixtures.

PCA calculation from this normalised data set indicated that the first two principal components accounted for the $81.6 \%$ of the total variability. The first and predominant PCA, PC1 contained $51.7 \%$ of the total variance and was a combination of PCB 52 and $132+105$ (Fig. 3(a)). The second principal component, PC2, contained $29.8 \%$ of the total variance and was mainly a combination of PCB 132+105, 153 and 180 (Fig. 3(a)). The plot of the scores is shown in Fig. 3(b) (see Table 1 for numbering). The studied samples distributed in the two-dimensional space according to geographical location where they were gathered. Vulture individuals from station 2 (class I) and station 5 (class II) formed welldefined classes clearly separated from each other and from the other colonies. Samples from stations 3 and 4 (class III) showed PCB profiles close to that of Aroclor 1260. Meanwhile, serum PCB profiles from stations 1 (class IV) and 2 were somewhat close to A-1254 and A1242, respectively. Finally, samples from station 5 were far from all PCB technical mixtures included in the
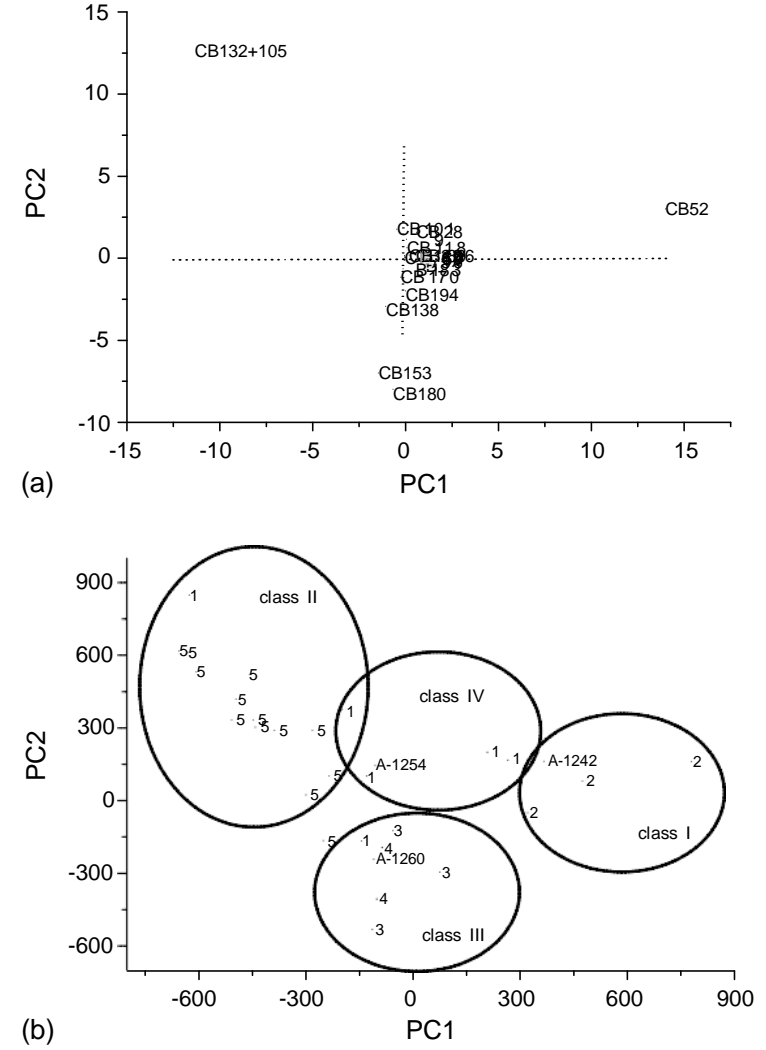

Fig. 3. Two-dimensional principal components loading (a) and score (b) plots of normalised PCB congeners in vulture serum from five Spanish populations. 
study. These results show that some differences can be observed in the individuals depending on sampling area: Fuerteventura Island (station 5) is a residential area located in the North African Atlantic Ocean, far from the rest of the sampling points, and without any industrial activity. Thereby, the PCB levels and profile found in these samples could be associated with long-range atmospheric transport and environmental degradation of these pollutants. This fate has been observed by other authors in different avian species (Elliott et al., 2000). The differences in the PCB profiles could be also associated with differences in metabolic activities caused by the presence of other contaminants. In addition to PCBs, other compounds could affect the PCB metabolism as other author suggested (van den Brink and Bosveld, 2001).

\section{Conclusions}

An SPE-based method has been used for the analysis of PCBs and DDTs in serum of Egyptian Vulture. The small amount of sample required, $=1 \mathrm{ml}$, has allowed monitoring of the concentration of these pollutants in live individuals of this endangered species. Levels detected in the five populations sampled are far below those considered to be a risk for the health of the populations. However, a $\mathrm{p}, \mathrm{p}^{0}-\mathrm{DDT} / \mathrm{p}, \mathrm{p}^{0}-\mathrm{DDE}$ ratio higher than one was obtained for one of the colonies, which could be considered as a possible indicator of recent use of this banned pesticide. The levels of DDTs found in the vultures appear to be related with their migratory habits. Meanwhile, the PCB profiles look to depend on the area where the birds live. Finally, the application of PCA uncovered the similarity of samples in relation to different technical PCB mixtures and demonstrated differences in PCB residue profiles for the five bird populations studied.

\section{Acknowledgements}

The authors thank Miss L. Herrero for her help on the analysis. Financial support was obtained from the Andalusian Regional Government and projects 2FD970621, CAL00-041 and 16/98-CSIC.

\section{References}

Ballschmiter, K., Zell, M., 1980. Analysis of polychlorinated biphenyls (PCBs) by glass capillary gas chromatography. Fresenius J. Anal. Chem. 302, 20-31.

de Boer, J., Stronck, C.J.N., Traag, W.A., van der Meer, J., 1993. Non-ortho and mono-ortho substituted chlorobiphenyls and dibenzo-p-dioxins and dibenzofurans in marine and freshwater fish and shellfish from The Netherlands. Chemosphere 26, 1823-1842.

Dirksen, S., Boudewijn, T.J., Slager, L.K., Mes, R.G., van Schaick, M.J.M., de Voogt, P., 1995. Reduce breeding success of cormorants (Phalacrocorax carbo sinensis) in relation to persistent organochlorine pollution of aquatic habitat in The Netherlands. Environ. Pollut. 88, 119132.

Donázar, J.A., Palacios, C.J., Gangoso, L., Ceballos, O., González, M.J., Hiraldo, F., 2002. Conservation status and limiting factors in the endangered population of Egyptian vulture (Neophron percnopterus) in the Canary Islands. Biological Conservation 107, 89-97.

Elliott, J.E., Machmer, M.M., Wilson, L.K., Henny, C.J., 2000. Contaminants in Ospreys from the Pacific Northwest: II. Organochlorine pesticides, polychlorinated biphenyls, and mercury, 1991-1997. Arch. Environ. Contam. Toxicol. 38, 93-106.

Fernández, M.A., Cuesta, S., Jiménez, O., García, M.A., Hernández, L.M., Marina, M.L., González, M.J., 2000. Organochlorine and heavy metal residues in the water/ sediment system of the Southeast Regional Park in Madrid, Spain. Chemosphere 41, 801-812.

Fernie, K.J., Bortolotti, G.R., Smits, J.E., Wilson, J., Drouillard, K.G., Bird, D.M., 2000. Changes in egg composition of american kestrels exposed to dietary polychlorinated biphenyls. J. Toxicol. Environ. Health A 60, 291-303.

Gómara, B., Fernández, M.A., Baos, R., Herrero, L., Jiménez, B., Abad, E., Hiraldo, F., Ferrer, M., Rivera, J., González, M.J., 2002a. Presence of organochlorine pollutants (PCDDs, PCDFs, PCBs and DDTs) in eggs of predatory birds from Dorrana National Park, Spain. Organohalogen Compd. 58, 441-444.

Gómara, B., Ramos, L., González, M.J., 2002b. Determination of polychlorinated biphenyls in small-size serum samples by solid-phase extraction followed by gas chromatography with micro-electron-capture detection. J. Chromatogr. B 766, 279-287.

Hoffman, D.J., Smith, G.J., Rattner, B.A., 1993. Biomarkers of contaminant exposure in common terns and black-crowned night herons in the Great Lakes. Environ. Toxicol. Chem. 12, 1095-1103.

Hoffman, D.J., Melancon, M.J., Klein, P.N., Eissemann, J.D., Spann, J.W., 1998. Comparative developmental toxicity of planar polychlorinated biphenyls congeners in chickens, american kestrels and common terns. Environ. Toxicol. Chem. 17 (4), 747-757.

Iseki, N., Iizuka, T., Hayama, S., Masunaga, S., Nakanishi, J., 2001. Accumulation profiles and burdens of dioxins, furans and dioxins-like PCBs in common cormorants (Phalacrocorax carbo), from Japan. Organohalogen Compd. 51, 336339.

Jiménez, B., Hernández, L.M., González, M.J., Eljarrat, E., Rivera, J., Fossi, M.C., 1998. Congener specific analysis of polychlorinated dibenzo-p-dioxins and dibenzofurans in crabs and sediment from the Venice and Orbetello lagoons, Italy. Environ. Sci. Technol. 32, 3853-3861.

Kannan, K., Kumar, K.S., Takasuga, T., Giesy, J.P., Masunaga, S., 2002. Accumulation and elimination of PCDD/ PCDF and organochlorine pesticides in bald eagles from Michigan, USA. Organohalogen Compd. 57, 431-434. 
Konstantinou, I.K., Goutner, V., Albanis, T.A., 2000. The incidence of polychlorinated biphenyls and organochlorine pesticide residues in the eggs of the cormorant (Phalacrocorax carbo sinensis): an evaluation of the situation in four Greek wetlands of international importance. Sci. Total Environ. 257, 61-79.

Kumar, K.S., Bowerman, W.W., Travis, D.V.L., Takasuga, T., Masunaga, S., 2002. Levels of PCDD/PCDF and dioxin-like PCBs in blood of black and turkey vultures from Savannah river site, South California, USA. Organohalogen Compd. $58,461-464$.

Moessner, S., Ballschmiter, K., 1997. Marine mammals as global pollution indicators for organochlorines. Chemosphere 34, 1285-1296.

Sericano, J.L., Wade, T.L., Atlas, E.L., Brooks, J.M., 1990. Historical perspective on the environmental bioavailability of DDT and its derivatives to Gulf of Mexico oysters. Environ. Sci. Technol. 24, 1541-1548.

Serrano, R., Fernández, M.A., Rabanal, R., Hernández, L.M., González, M.J., 2000. Congener-specific determination of polychlorinated biphenyls in shark and grouper livers from Northwest African Atlantic Ocean. Arch. Environ. Contam. Toxicol. 38, 217-224.

Solé, M., Porte, C., Pastor, D., Albaigés, J., 1994. Long-term trends of polychlorinated biphenyls and organochlorinated pesticides in mussels from the Western Mediterranean coast. Chemosphere 28 (5), 897-903.

Tanabe, S., Tatsukawa, R., 1991. Persistent organochlorines in marine mammals. In: Jones, K.C. (Ed.), Organic Contaminants in the Environment: Environmental Pathways and Effects. Elsevier Applied Science Publishers, New York, USA, p. 275. van den Berg, M., Birnbaum, L., Bosveld, A.T.C., Brunstr6m, B., Cook, P., Feeley, M., Giesy, J.P., Hanberg, A., Hasegawa, R., Kennedy, S.W., Kubiak, T., Larsen, J.C., van Leeuwen, F.X.R., Liem, A.K.D., Nolt, C., Peterson, R.E., Poellinger, L., Safe, S., Schrenk, D., Tillitt, D., Tysklind, M., Younes, M., Waern, F., Zacharewski, T., 1998. Toxic equivalency factors (TEF) for PCBs, PCDDs, PCDFs for humans and wildlife. Environ. Health Perspect. 106, 775-792.

van den Brink, N.W., Bosveld, T.C., 2001. PCB concentrations and metabolism patterns in common terns (Sterna hirundo) from different breeding colonies in The Netherlands. Mar. Pollut. Bull. 42 (4), 280-285.

van Wyk, E., van der Bank, F.H., Verdoorn, G.H., 1993a. The cappe griffon (Gyps coprotheres) - a conservation priority. Vulture News 29, 4-18.

van Wyk, E., van der Bank, F.H., Verdoorn, G.H., Bouwman, H., 1993b. Chlorinated hydrocarbon insecticide residues in the cape griffon vulture (Gyps coprotheres). Comp. Biochem. Physiol. C 104, 209-220.

van Wyk, E., Bouwman, H., van der Bank, H., Verdoorn, G.H., Hofmann, D., 2001. Persistent organochlorine pesticides detected in blood and tissues samples of vultures from different localities in South Africa. Comp. Biochem. Physiol. C 129, 243-264.

WHO, 1989. Environmental Health Criteria 83: p,p $\mathrm{p}^{0}$-DDT and its derivatives-environmental aspects. World Health Organization, Geneva, Switzerland.

Wold, S., Albano, C., Dunn III, W.J., Edlund, U., Esbensen, K., Geladi, P., Hellberg, S., Johansson, E., Lindberg, W., Sjostrom, M., 1984. Chemometrics, theory and applications. Reidel D Publ Co, Dordrecht, Holland. 